\title{
Penerepan Kompres Dingin Pada Anak Usia Sekolah (6-12 Tahun) Untuk Mengatasi Nyeri Pemasangan Infus: Literature Review
}

\author{
Khofifah Tya Saputri ${ }^{1 *}$, Siti Rofiqoh ${ }^{2}$ \\ 1,2 Program Studi Diploma Tiga Keperawatan, Universitas Muhammadiyah Pekajangan \\ Pekalongan, Indonesia \\ *email: tya.saputri73@gmail.com
}

\begin{abstract}
One of the non-pharmocological therapis to treat infusion pain is cold compress therapy. This study aims to investigate how cold compress therapy can overcome infusion pain. It is a literature review with three articles taken from Google Scholar, with cold compress, school age children, and infusion pain as the key. Those are full text article and published in 20132020. It took from 86 respondents, male (65\%) and female (35\%), with the age from 6 to 12 yers old. The result show to those who were given the therapy has light pain with the avarage value 2,50 . Otherwise, those who were not given the one, has a light pain with the avarage value 6,09 . Therefore, it can be concluded the cold compress therapy can overcome infusion pain in school age children (6-12) yers old. And, it is expected for health services to apply this therapy.
\end{abstract}

Keywords: school age children, cold compress, infusion pain

\begin{abstract}
Abstrak
Salah satu terapi non farmakologi untuk mengatasi nyeri pemasangan infus adalah terapi pemberian kompres dingin. Penelitian ini bertujuan untuk menggambarkan terapi kompres dingin pada anak untuk mengatasi nyeri pemasangan infus. Desain karya tulis ilmiah berupa literatur review dengan jumlah tiga artikel yang diambil dari laman google scholar dengan kata kunci "kompres dingin", "anak usia sekolah", dan "nyeri pemasangan infus" berupa artikel fulltex, terbit tahun 2013-2020. Hasil analisa karekteristik responden dari ketiga artikel menunjukkan jumlah responden 86 , sebagian besar laki-laki (65\%) dan (35\%) perempuan, umur 6-12 tahun. Nyeri pada kelompok yang diberikan kompres dingin yaitu nyeri ringan dengan nilai rata-rata $(2,50)$ dan yang tidak diberikan kompres dingin yaitu nyeri sedang dengan nilai rata-rata $(6,09)$. Kesimpulannya adalah terapi kompres dingin dapat mengatasi nyeri saat pemasangan infus pada anak usia sekolah (6-12 tahun). Saran bagi pelayanan kesehatan untuk menerapkan terapi kompres dingin untuk mengatasi nyeri saat pemasangan infus pada anak usia sekolah (6-12 tahun).
\end{abstract}

Kata kunci: Anak usia sekolah; Kompres dingin; Nyeri pemasangan infus

\section{Pendahuluan}

Anak merupakan individu yang unik dan berbeda dengan orang dewasa. Anak usia sekolah merupakan periode usia pertengahan dimulai dari usia $6-12$ tahun yang sangat rentan terhadap penyakit disebabkan karena faktor lingkungan, kebersihan, dan gizi yang kurang sehat sehingga kemungkinan besar menyebabkan penyakit timbul. Anak adalah individu yang masih bergantung pada orang dewasa dan lingkungannya, artinya membutuhkan lingkungan untuk memenuhi kebutuhan dasar dan belajar mandiri. Anak yang mengalami sakit memerlukan pengobatan sehingga anak harus dirawat dirumah sakit (Hospitalisasi) untuk proses penyembuhan (Wong, 2012 ). 


\section{Prosiding Seminar Nasional Kesehatan Lembaga Penelitian dan Pengabdian Masyarakat Universitas Muhammadiyah Pekajangan Pekalongan}

Stresor utama dari hospitalisasi adalah perpisahan, kehilangan kendali, cedera tubuh, dan nyeri. Pemasangan infus merupakan sumber kedua dari nyeri yang paling sering dirasakan anak setelah penyakit yang dideritanya (Kennedy, Luhmann \& Zempsky, 2008). Tindakan ini dilakukan dengan memasukkan jarum ke dalam pembuluh darah pada anak yang mengakibatkan nyeri. Pemasangan infus digunakan untuk pemberian cairan, nutrisi, dan pemberian obat secara terus menerus (Potter \& Perry, 2013). Pemasangan infus sangat bermanfaat untuk pemberian obat pada anakanak yang mengalami diare, dehidrasi, anak yang membutuhkan obat parenteral untuk waktu yang lama dan anak memerlukan pengobatan darurat (Wong, 2009).

American Heart Association (AHA) tahun 2012, menyatakan dampak yang ditimbulkan akibat prosedur tindakan invasif akan menimbulkan rasa nyeri sehingga anak akan mengalami kecemasan dan stress. Nyeri yang tidak ditangani akan berdampak pada anak dapat mengganggu aktivitas sehingga menyebabkan kesulitan berinteraksi dengan orang lain karena anak akan berfokus pada nyeri yang dirasakan. Dampaknya akan menghambat perkembangan secara kognitif, fisik, emosional maupun sosial. Tingkat nyeri anak dapat diukur dengan skala penilaian nyeri menggunakan skala face (wajah), legs (tungkai), activity (gerakan), cry (tangisan), consolability (dapat dihibur) biasanya disingkat (FLACC). FLACC adalah suatu alat pengukuran rasa nyeri tes kemampuan berdasarkan tingkah laku anak (Potter \& Peryy, 2013). Pengurangan nyeri merupakan kebutuhan dasar dan hak semua anak. Metode pengurangan nyeri dapat dikelompokkan menjadi dua kategori yaitu non farmakologi dan farmakologi. Farmakologi merupakan teknik mengurangi nyeri menggunakan obatobatan dan non farmakologi tanpa menggunkan obat-obatan meliputi relaksasi, hipnotis, guided imagery, massage, terapi musik, kompres hangat dan kompres dingin (Docher, 2013). Kompres dingin merupakan terapi nonfarmakologi yang cocok diberikan sebelum dilakukan pemasangan infus. Pemberian kompres dingin pada anak usia sekolah dapat mengatasi nyeri pemasangan infus sebab rasa dingin akan menimbulkan mati rasa sebelum rasa nyeri timbul. Kompres dingin menggunakan es untuk memperlambat dan menurunkan inflamasi sehingga dapat menimbulkan efek anestesi lokal pada luka tusuk akibat pemasangan infus (Potter \& Perry, 2013).

Berdasarkan uraian di atas, penulis tertarik menyusun Karya Tulis Ilmiah dengan judul "Penerapan Kompres Dingin Pada Anak Usia Sekola (6-12 Taun) Untuk Mengatasi Nyeri Pemasangan Infus: Literature review".

\section{Literature review}

Nyeri secara umum adalah suatu kondisi yang tidak nyaman, baik ringan maupun berat. Nyeri pada anak biasanya traumatik yang tidak menyenangkan. Nyeri yang tidak titangani akan berdampak pada anak dapat mengganggu aktivitas sehingga menyebabkan kesulitan berinteraksi dengan orang lain oleh orang lain karena anak akan berfokus pada nyeri yang dirasakan. ketidakmampuan untuk mengurangi nyeri dapat menimbulkan ketidak berdayaan dan keputusasaan (Wong, 2012). Pemasangan infus merupakan sumber kedua dari nyeri yang paling sering dirasakan anak setelah penyakit yang dideritanya (Kennedy, Luhmann \& Zempsky, 2008). Tindakan ini 


\section{Prosiding Seminar Nasional Kesehatan Lembaga Penelitian dan Pengabdian Masyarakat Universitas Muhammadiyah Pekajangan Pekalongan}

dilakukan dengan memasukkan jarum ke dalam pembuluh darah pada anak yang mengakibatkan nyeri (Indriyani, 2013).

Kompres dingin adalah pemberian respon kulit menggunakan kantong es untuk mengurangi nyeri. Kompres dingin merupakan terapi nonfarmakologi yang cocok diberikan sebelum dilakukan pemasangan infus. Menurut Prasetyo (2013) kompres dingin menstimulasi permukaan kulit untuk mengontrol nyeri diketahui lebih efektif dan efesien untuk menghalangi impuls nyeri, pada umumnya dingin lebih mudah menembus jaringan ketika otot mengalami penurunan suhu akibat efek dingin. Nyeri yang dirasakan akan berkurang atau hilang untuk sementara waktu (Nurchairiah, 2015). Pada kompres dingin lebih dominan dalam persepsi nyeri sehingga menimbulkan rasa dingin salah satunya anak akan merasa lebih nyaman (Kozler, 2012).

\section{Metode}

Rancangan karya tulis ilmiah Literatur review adalah mengkaji atau meninjau secara pengetahuan, gagasan atau temuan yang terdapat dalam bentuk metodologi dikategorikan sebagai sebuah karya tulis ilmiah dengan menggunakan cara mengkomplikasi, mengklarifikasi, dan mengevaluasi apa yang ditulis peneliti pada topik yang telah ditentukan (Zed, 2014).

Subyek karya tulis ilmiah adalah anak usia sekolah (6-12 tahun) kriteria insklusinya anak usia sekolah yang mengalami nyeri pemasangan infus dapat diukur menggunakan skala numeric. Dan kriteria ekslusinya anak usia sekolah yang merasakan nyeri hebat dari penyakit yang dialami, anak yang hipersensitif terhadap suhu dingin. Metode pengumpulan data berdasarkan pencarian hasil literatur review menggunakan pencarian di google menggunkan desain eksperimental dengan jumlah 86 responden.

Definisi operasional untuk mengukur skala nyeri menggunakan Numeric rating scale yaitu anak diminta untuk memilih angka antara 0-10, 0 menandakan tidak nyeri dan 10 menandakan nyeri yang sangat hebat. Faces pain rating scale yaitu skala yang terdapat gambar wajah mulai dari tidak ada rasa sakit (senang) sampai paling sakit (menangis), jumlah skor diperoleh antara 0-10 dengan cara menunjukkan gambar untuk menentukan atau memilih ekspresi wajah anak. FLACC yaitu pengengukuran mulai dari wajah, tungkai, gerakan, tangisan, dan dapat dihibur dengan skor total 0 (tidak nyeri) dan 10 (nyeri hebat).

\section{Hasil dan Pembahasan Hasil}

Hasil Literature Review menampilkan data karakteristik demografi (umur, jenis kelamin, pengalaman infus dan nilai rata-rata). Karakteristik tersebut dijelaskan pada tabel 1.distribusi frekuensi responden berdasarkan umur $(n=86)$. Jenis kelamin dijelaskan pada tabel 2.distribusi frekuensi responden berdasarkan jenis kelamin ( $\mathrm{n}=$ 86). Pengalaman infus dijelaskan pada tabel 3.distribusi frekuensi responden berdasarkan pengalaman infus $(n=86)$. sedangkan Nilai rata-rata dijelaskan pada tabel 4.Rata-rata tingkat nyeri responden yang diberikan kompres dingin dan tidak diberikan kompres dingin pada saat pemasangan infus $(n=86)$. 


\section{Prosiding Seminar Nasional Kesehatan \\ Lembaga Penelitian dan Pengabdian Masyarakat Universitas Muhammadiyah Pekajangan Pekalongan}

Tabel 4.1 Distribusi Frekuensi Responden Berdasarkan Umur $(\mathrm{n}=86)$

\begin{tabular}{|c|c|c|c|c|c|c|c|c|c|}
\hline \multirow[t]{2}{*}{ Karakteristik } & \multirow[t]{2}{*}{ Umur } & \multicolumn{2}{|c|}{$\begin{array}{c}\text { Artikel } 1 \\
\mathrm{n}=30\end{array}$} & \multicolumn{2}{|c|}{$\begin{array}{c}\text { Artikel } 2 \\
\mathrm{n}=36\end{array}$} & \multicolumn{2}{|c|}{$\begin{array}{c}\text { Artikel } 3 \\
\mathrm{n}=20\end{array}$} & \multicolumn{2}{|c|}{$\begin{array}{c}\text { Total } \\
\mathrm{n}=86\end{array}$} \\
\hline & & $\mathrm{F}$ & $\%$ & $\mathrm{~F}$ & $\%$ & $\mathrm{~F}$ & $\%$ & $F$ & $\%$ \\
\hline \multirow{7}{*}{$\begin{array}{l}\text { Diberikan } \\
\text { kompres } \\
\text { dingin }\end{array}$} & 6 tahun & - & - & 5 & 27,8 & 3 & 30 & 8 & 28,6 \\
\hline & 7 tahun & - & - & 3 & 16,7 & 1 & 10 & 4 & 14,3 \\
\hline & 8 tahun & - & - & 4 & 22,2 & 1 & 10 & 5 & 17,9 \\
\hline & 9 tahun & - & - & 3 & 16,7 & 2 & 20 & 5 & 17,9 \\
\hline & 10 tahun & - & - & 1 & 5,6 & 2 & 20 & 3 & 10,7 \\
\hline & 11 tahun & - & - & 0 & 0 & 1 & 10 & 1 & 3,5 \\
\hline & 12 tahun & - & - & 2 & 11,1 & - & 0 & 2 & 7,1 \\
\hline \multirow{7}{*}{$\begin{array}{l}\text { Tidak } \\
\text { diberikan } \\
\text { kompres } \\
\text { dingin }\end{array}$} & 6 tahun & - & - & 5 & 27,8 & 4 & 40 & 9 & 32,1 \\
\hline & 7 tahun & - & - & 3 & 11,1 & 2 & 20 & 5 & 17,9 \\
\hline & 8 tahun & - & - & 2 & 5,6 & 1 & 10 & 3 & 10,7 \\
\hline & 9 tahun & - & - & 0 & 0 & - & 0 & 0 & 0 \\
\hline & 10 tahun & - & - & 1 & 11,1 & 2 & 20 & 3 & 10,7 \\
\hline & 11 tahun & - & - & 2 & 16,7 & 1 & 10 & 3 & 10,7 \\
\hline & 12 tahun & - & - & 5 & 27,8 & - & 0 & 5 & 17,9 \\
\hline
\end{tabular}

Diketahui pada Tabel 4.1 karakteristik berdasarkan usia dari 28 responden yang diberikan kompres dingin terbanyak berusia 6 tahun sejumlah $8(28,6 \%)(n=28)$. Sedangkan tidak diberikan kompres dingin usia terbanyak 6 tahun sejumlah $9(32,1 \%)$ $(n=28)$.

Tabel 4.2 Distribusi Frekuensi Responden Berdasarkan Jenis Kelamin $(n=86)$

\begin{tabular}{|c|c|c|c|c|c|c|c|c|c|}
\hline \multirow[t]{2}{*}{ Karakteristik } & \multirow[t]{2}{*}{ Jenis kelamin } & \multicolumn{2}{|c|}{$\begin{array}{c}\text { Artikel } 1 \\
n=30\end{array}$} & \multicolumn{2}{|c|}{$\begin{array}{c}\text { Artikel } 2 \\
n=36\end{array}$} & \multicolumn{2}{|c|}{$\begin{array}{c}\text { Artikel } 3 \\
n=20\end{array}$} & \multicolumn{2}{|c|}{$\begin{array}{c}\text { Total } \\
\mathrm{n}=86\end{array}$} \\
\hline & & $\mathrm{F}$ & $\%$ & $\mathrm{~F}$ & $\%$ & $F$ & $\%$ & $\mathrm{~F}$ & $\%$ \\
\hline \multirow{2}{*}{$\begin{array}{c}\text { Diberikan } \\
\text { kompres dingin }\end{array}$} & Laki-laki & 11 & 73,3 & 11 & 61,1 & 5 & 50 & 27 & 62,8 \\
\hline & Perempuan & 4 & 26,6 & 7 & 38,9 & 5 & 50 & 16 & 37,2 \\
\hline \multirow[t]{2}{*}{$\begin{array}{l}\text { Tidak diberikan } \\
\text { kompres dingin }\end{array}$} & Laki-laki & - & - & 11 & 61,1 & 7 & 70 & 18 & 64,3 \\
\hline & Perempuan & - & - & 7 & 38,9 & 3 & 30 & 10 & 35,7 \\
\hline
\end{tabular}




\section{Prosiding Seminar Nasional Kesehatan Lembaga Penelitian dan Pengabdian Masyarakat Universitas Muhammadiyah Pekajangan Pekalongan

Diketahui pada Tabel 4.2 karakteristik responden berdasarkan jenis kelamin diberikan kompres dingin $(n=43)$ jenis kelamin laki-laki sejumlah $27(62,8 \%)$ dan perempuan sejumlah $16(37,2 \%)$ sedangkan tidak diberikan kompres dingin $(n=28)$ jenis kelamin laki-laki sejumlah 18 (64,3\%) dan perempuan sejumlah 10 (35,7\%).

Tabel 3. Distribusi Frekuensi Responden Berdasarkan Pengalaman Infus $(n=86)$

\begin{tabular}{|c|c|c|c|c|c|c|c|c|c|}
\hline \multirow[t]{2}{*}{ Karakteristik } & \multirow[t]{2}{*}{$\begin{array}{l}\text { Pengalaman } \\
\text { Infus }\end{array}$} & \multicolumn{2}{|c|}{$\begin{array}{c}\text { Artikel } 1 \\
n=30\end{array}$} & \multicolumn{2}{|c|}{$\begin{array}{c}\text { Artikel } 2 \\
n=36\end{array}$} & \multicolumn{2}{|c|}{$\begin{array}{c}\text { Artikel } 3 \\
n=20\end{array}$} & \multicolumn{2}{|c|}{$\begin{array}{c}\text { Total } \\
n=86\end{array}$} \\
\hline & & $\mathrm{F}$ & $\%$ & $\mathrm{~F}$ & $\%$ & $\mathrm{~F}$ & $\%$ & $\mathrm{~F}$ & $\%$ \\
\hline \multirow{2}{*}{$\begin{array}{c}\text { Diberikan } \\
\text { kompres } \\
\text { dingin }\end{array}$} & Pernah & 9 & 60 & 12 & 66,7 & 2 & 20 & 23 & 53,5 \\
\hline & Belum pernah & 6 & 40 & 6 & 33,3 & 8 & 80 & 20 & 46,5 \\
\hline \multirow{2}{*}{$\begin{array}{c}\text { Tidak } \\
\text { diberikan } \\
\text { kompres } \\
\text { dingin }\end{array}$} & Pernah & - & - & 8 & 44,4 & 2 & 20 & 10 & 35,7 \\
\hline & Belum pernah & - & - & 10 & 55,6 & 8 & 80 & 18 & 64,3 \\
\hline
\end{tabular}

Diketahui pada Tabel 4.3 Karateristik responden berdasarkan pengalaman infus yang diberikan kompres dingin $(n=43)$ yang pernah dilakukan infus sejumlah 23 $(53,5 \%)$ dan belum pernah dilakukan pemasangan infus sejumlah 20 (46,5\%), sedangkan tidak diberikan kompres dingin $(n=28)$ yang pernah dilakukan pemasangan infus sejumlah $10(35,7 \%)$ dan belum pernah dilakukan pemasangan infus sejumlah 18 (64,3\%).

Tabel 4.4 Rata-rata tingkat nyeri responden yang diberikan kompres dingin dan tidak diberikan kompres dingin pada saat pemasangan infus $(n=86)$

\begin{tabular}{cccc}
\hline & \multicolumn{3}{c}{ Nilai Rata-Rata } \\
\cline { 2 - 4 } Artikel & $\begin{array}{c}\text { Diberikan kompres } \\
\text { dingin }\end{array}$ & $\begin{array}{c}\text { Tidak diberikan } \\
\text { kompres dingin }\end{array}$ & P. Value \\
Artikel 1 & 2,53 & 6,93 & 0,0001 \\
$\mathrm{n}=30$ & 2,11 & 4,28 & 0,00 \\
Artikel 2 & & 0,000 \\
$\mathrm{n}=36$ & 2,75 & 6,40 & $<0,05$ \\
Artikel 3 & & 6,09 & \\
$\mathrm{n}=20$ & 2,5 & & \\
\hline $\begin{array}{c}\text { Total } \\
\mathrm{n}=86\end{array}$ & & & \\
\hline
\end{tabular}

Hasil Analisa Data Tabel 4.4 rata-rata tingkat nyeri kelompok responden yang diberikan kompres dingin 2,5 dan tidak diberikan kompres dingin 6,09. Hasil P Value $<$ 0,05 . 


\section{Prosiding Seminar Nasional Kesehatan 2021 Lembaga Penelitian dan Pengabdian Masyarakat Universitas Muhammadiyah Pekajangan Pekalongan}

\section{Pembahasan}

Hasil review berdasarkan table 1 menunjukkan bahwa rata-rata nyeri pemasangan infus pada kelompok yang tidak diberikan kompres dingin artikel $1(6,93)$ artikel 2 $(4,28)$ artikel $3(6,40)$ dengan rata-rata nyeri 6,09 merupakan kategori nyeri sedang. Nyeri sedang yang dialami responden pada kelompok yang tidak diberikan kompres dingin dapat terjadi karena sebagian besar responden anak usia 6 tahun. Hal ini dapat dilihat pada tabel 1 anak yang berusia lebih kecil pada umumnya mengalami sakit nyeri yang lebih berat dibandingkan usia yang lebih besar karena saat dilakukan penusukan jarum infus ke pembuluh darah menimbulkan rangsangan yang mengganggu sehingga akan menyebabkan kerusakan jaringan dan menimbulkan rasa nyeri. Selain faktor dari usia, pengalaman infus juga mempengaruhi nyeri karena dari ketiga artikel yang direview jumlah responden yang belum pernah dilakukan pemasangan infus lebih banyak dengan jumlah 18 (64,3\%) daripada yang pernah dilakukan pemasangan infus. Belum adanya pengalaman di infus terkait dengan nyeri membuat anak dapat mengalami kecemasan dan akan lebih fokus terhadap rasa sakit dibandingkan yang pernah dilakukan pengalaman pemasangan infus rasa nyeri akan lebih sedikit (Smetlzer \& Bare, 2010).

Nyeri akibat pemasangan infus beresiko efek jangka panjang, luka yang lama, penurunan sistem imun. Menurut (Imami nur, 2008) mekanisme di otak seperti sebuah gerbang akan meningkatkan atau mengurangi impuls saraf ke sistem saraf pusat. Jika pada kelompok yang tidak diberikan kompres dingin, nyeri saat pemasangan infus akan lebih besar dan lebih lama sehingga perlu adanya terapi untuk menurunkan intensitas nyeri dengan menerapkan terapi kompres dingin yang dapat mengatasi nyeri pemasangan infus. Karena kompres dingin dapat menurunkan tingkat nyeri dengan memberikan efek fisiologis pada tubu yang dapat meredakan nyeri seperti obat yang menyebabkan tidak adanya sensasi nyeri (Indriyani, Hayati, dan Chodidjah, 2013).

Hal yang dapat terjadi selain pemberian kompres dingin dapat menurunkan nyeri, jenis kelamin juga dapat berpengaruh terhadap respon nyeri anak. Berdasarkan tabel 2 pada kelompok yang diberikan kompres dingin berjenis laki-laki yaitu sebanyak 27 $(62,8 \%)$ jenis kelamin laki-laki akan berespon nyeri lebih rendah, perempuan secara konsisten bahwa intensitas nyeri lebih tinggi dibandingkan laki-laki. Dalam kebudayaan juga menjelaskan bahwa jenis kelamin dapat mempengaruhi respon individu terhadap nyeri. Seorang anak laki-laki dalam kebudayaan dituntut untuk berani dan tidak boleh menangis sedangkan perempuan diperbolehkan menangis dalam situasi yang sama. Kemungkinan nyeri anak laki-laki lebih rendah secara signifikan dibandingkan perempuan (Potter \& Perry, 2013).

Berdasarkan tabel 4 menunjukkan skor nyeri pada kelompok yang diberikan kompres dingin saat pemasangan infus lebih kecil dibanding kelompok yang tidak diberikan kompres dingin. Pemberian kompres dingin dapat meningkatkan pelepasan endorfin yang memblok tranmisi stimulasi nyeri dan menstimulasi serabut saraf. Adanya kompres dingin ini mampu mengatasi nyeri pemasangan infus karena akan memperlambat konduksi serabut saraf perifer, melindungi jaringan dari penyebaran infeksi dan reseptor ujung saraf yang ada dikulit akan merasa lebih dingin sehingga efek rasa nyeri lebih sedikit. Penurunan rata-rata nyeri saat pemasangan infus pada 


\section{Prosiding Seminar Nasional Kesehatan 2021 Lembaga Penelitian dan Pengabdian Masyarakat Universitas Muhammadiyah Pekajangan Pekalongan}

kelompok yang diberikan kompres dingin lebih dominan dibandingkan dengan yang tidak diberikan kompres dingin karena manfaat dalam penggunaan kompres dingin dapat menurunkan aliran darah ke daerah tubuh yang mengalami nyeri daripada kelompok tidak diberikan kompres dingin tidak ada yang memblok tranmisi serabut saraf mengakibatkan nyeri lebih tinggi (Seingo, sudiwati dan Dewi, 2017).

\section{Kesimpulan}

Berdasarkan Hasil review tentang "Penerapan kompres dingin pada anak usia sekolah (6-12 tahun) untuk mengatasi nyeri pemasangan infus" dapat disimpulkan bahwa rata-rata tingkat nyeri dari 43 responden pada kelompok yang diberikan kompres dingin adalah 2,50 sedangkan rata-rata tingkat nyeri dari 43 responden pada kelompok yang tidak diberikan kompres dingin adalah 6,09 dengan Hasil P. Value < 0,05 menunjukkan ada pengaruh kompres dingin terhadap nyeri pemasangan infus pada anak usia sekolah.

\section{Referensi}

[1] Anisa, O. (2018). Konsep Dan Aplikasi Keperawatan Anak. Jakarta, Trans Info Media.

[2] Asriani, N, K., Lestiawati, E., and Retnaningsih, L, E. "Pengaruh kompres dingin terhadap tingkat nyeri anak usia sekolah saat pemasanggan infus di poliklinik persiapan rawat inap RSUD panemahan senopati bantul". Jurnal Keperawatan Respati Yogyakarta, vol. 4, No. 1, pp. 70-75, 2017.

[3] Bahrudin, M. "Patofisiologi Nyeri". Ejournal.umm.ac.id, Vol. 13, No. 1, pp. 7-13, 2017.

[4] DPP. PPNI. (2016). "Standar Diagnosa Keperawatan Indonesia". Jakarta Selatan, Indonesia : Dewan Pengurus Pusat Persatuan Perawat Nasional Indonesia.

[5] Endiyono., Ramadani, L, M. "Pengaruh kompres dingin terhadap tingkat persepsi nyeri insersi arteriovenosa fistula pada pasien hemodialisasi dirumah sakit umum daerah purbalingga". Jurnal medika, Vol. 12, No. 3, pp. 26-31, 2017.

[6] Iklima, N., Mediani, H. S., and Prawesti, A. "Pengkajian dan manajemen nyeri diruang intensif literatur review". Journal.ppnijateng.org. Vol. 3, No. 1, pp. 1124, 2019.

[7] Indriyani, P., Hayati, H., Choididjah, S. "Kompres dingin dapat menurunkan nyeri anak usia sekolah saat pemasangan infus". Jurnal Keperawatan Indonesia., Vol. 16 No. 2, pp. 93-100, 2013

[8] Kozier, B. (2012). "Buku Ajar Praktik Klinis". Jakarta : BCG

[9] Laksmi, I. G., Suryati, N. M., Yanti, N. L. "Pengaruh kompres dinginterhadap tingkat nyeri saat pemasangan infus pada anak usia sekolah". balimedikajurnal.com, Vol. 5, No. 2, pp. 198-209, 2018.

[10] Lestiawati, E., Krisnanto, D, P. "Faktor Yang Berhubungan Dengan Tingkat Nyeri Pemasangan Infus Pada Anak Usia Sekolah". Universitas Respati Yogyakarta, 


\section{Prosiding Seminar Nasional Kesehatan 2021 Lembaga Penelitian dan Pengabdian Masyarakat Universitas Muhammadiyah Pekajangan Pekalongan}

2016

Diambil

dari

https://medika.respati.ac.id/index.php/Medika/article/download/39/37

[11] Potter, P. A \& Perry, A. G. (2013). Buku ajar fundamental keperawatan: konsep proses dan praktek: Yasmin Asih. Jakarta : ECG.

[12] Prasetyo, S.N. (2013). Konsep dan proses keperawatan nyeri. Yogyakarta : Graha Ilmu.

[13] Racmawati, I, N. "Analisa Teori Nyeri Keseimbangan Antara Analgesik Dan Efek Samping". Jurnal Keperawatan Indonesia, Vol. 12, No. 2, pp. 129-136, 2008.

[14] Seingo, F., Sudiawati, N, L., Dewi, N. "Pengaruh Kompres Dingin Terhadap Penurunan Intensitas Nyeri Pada Wanita Yang Mengalami Disminore Di Rayon Ikabel Tlogomas". Nursing news, Vol. 3, No. 1, pp. 153-163, 2018.

[15] Smeltzer \& Bare. (2013). Buku ajar keperawatan medikal bedah : Brunner \& suddarth. Jakarta : ECG.

[16] Supartini, Y. (2012). Buku Ajar Konsep Dasar Keperawatan Anak. Jakarta, Indonesia : EGC.

[17] Tamsuri, Anas. (2012). Konsep dan penatalaksanaan nyeri. Jakarta : EGC

[18] Utami, Y. "Dampak hospitalisasi terhadap perkembangan anak". Jurnal ilmiah WIDYA, Vol. 2, No. 2, pp. 9-20, 2014.

[19] Wong, D, L. (2012). Pedoman klinis keperawatan pediatrik, edisi 4. Jakarta : ECG.

[20] Zed, M. (2014). Metode Penelitian Kepustakaan. Jakarta : Yayasan Obor Indonesia. 